\title{
Survival of a plasmid-bearing strain of Bacillus subtilis introduced into compost
}

\author{
Wendy Amner, Alan J. McCarthy* and Clive Edwards \\ Department of Genetics and Microbiology, University of Liverpool, PO Box 147, Liverpool L69 3BX, UK
}

(Received 1 October 1990; revised I May 1991; accepted 3 May 1991)

\begin{abstract}
Survival of Bacillus subtilis strain 168 containing plasmid pAB224, which carries a gene for tetracycline resistance, was studied in mushroom compost under mesophilic and thermophilic conditions. Stable populations of $B$. subtilis were maintained as spores in both sterile and fresh mushroom compost incubated at $37^{\circ} \mathrm{C}$. At $65^{\circ} \mathrm{C}$, the introduced $B$. subtilis populations declined during incubation but spores were still detectable after $28 \mathrm{~d}$. Survival at the higher temperature was greater in fresh than in sterile compost. There was no apparent loss of plasmid pAB224 or plasmid-determined phenotype from the introduced $B$. subtilis population at either incubation temperature. The frequency of tetracycline resistance in the indigenous Bacillus population was very low $\left(10^{-5}\right)$, but some tetracycline-resistant isolates contained plasmid DNA. Four plasmid DNA profiles were found associated with five Bacillus phenotypes, and some evidence for homology with pAB224 was found. However, pAB224 was found to be a suitable marker for release studies because it was easily recovered, readily distinguished from indigenous plasmids on agarose gels, and was maintained in compost-grown $B$. subtilis 168 in the absence of any selective pressure.
\end{abstract}

\section{Introduction}

Bacillus species are important commercial sources of a variety of industrial enzymes including extracellular proteases and amylases (Priest, 1977). In addition, the insecticidal properties of Bacillus thuringiensis are widely employed for the bio-control of insect pests (Payne, 1988). Introduction of cloned genes into Bacillus spp. via plasmid vectors can be used to improve the efficacy of some strains (Aiba et al., 1983; Miyagawa et al., 1989; Nakamura \& Imanaka, 1989). Consequently concerns have been raised over the deliberate or accidental release of recombinant Bacillus strains into the environment, and the potential for gene survival and transfer. Microcosm studies aimed at assessing the risks involved in the release of genetically engineered micro-organisms have been carried out for a number of species under a range of environmental conditions (e.g. Stotzky \& Babich, 1986; Trevors et al., 1987). However, such studies have mainly focussed on survival and gene exchange among introduced Gram-negative bacteria (Bentjen et al., 1989; Devanas \& Stotzky, 1986; Genthner et al., 1988; Krasovsky \& Stotzky, 1987; Morel et al., 1989; Richaume et al., 1989; Trevors \& Berg,
1989). Microcosm studies on gene exchange between Gram-positive species have been limited to recent reports of conjugal plasmid transfer between Streptomyces spp. (Bleakley \& Crawford, 1989; Rafii \& Crawford, 1988; Wang et al., 1989; Wellington et al., 1988), transformation of Bacillus subtilis in sterile soil (Graham \& Istock, 1978) and conjugal gene transfer between Bacillus cereus and B. subtilis in both sterile and non-sterile soil (Van Elsas et al., 1987). There have also been a few investigations on survival of Bacillus strains in rhizosphere and non-rhizosphere soils (Acea et al., 1988; Van Elsas et al., 1987, 1988).

In the work described here, we examined survival of $B$. subtilis in commercially produced mushroom compost, an environment where biological activity is high and where Bacillus spp. are present in large numbers (Amner et al., 1988). Survival of both the host and the nontransmissible plasmid pAB224, which encodes tetracycline resistance (Bingham et al., 1980), were monitored under mesophilic $\left(37^{\circ} \mathrm{C}\right)$ and thermophilic $\left(65^{\circ} \mathrm{C}\right)$ conditions. The suitability of tetracycline as a marker for these studies was further assessed by examining plasmid DNA in the indigenous tetracycline-resistant Bacillus population of compost. 


\section{Methods}

Isolation of tetracycline-resistant bacteria from compost. Mushroom compost samples were collected at the end of phase II of commercial preparation, as described previously (Amner et al., 1988). Tetracyclineresistant strains of thermophilic bacteria were isolated from compost samples by dilution plating onto nutrient agar, NA ( $\mathrm{Lab} \mathrm{M}$ ), containing $25 \mu \mathrm{g}$ tetracycline $\mathrm{ml}^{-1}$. The plates were incubated at $50^{\circ} \mathrm{C}$ overnight and colonies purified by subculturing on the same medium. Strains were maintained on NA containing tetracycline and as stocks in $15 \%$ (v/v) glycerol stored at $-70^{\circ} \mathrm{C}$.

Screening for plasmids. Tetracycline-resistant isolates were inoculated into $5 \mathrm{ml}$ nutrient broth (NB) containing $10 \mu \mathrm{g}$ tetracycline $\mathrm{ml}^{-1}$ and incubated with shaking at $50^{\circ} \mathrm{C}$ overnight. Harvested cultures were then subjected to a rapid alkaline extraction procedure (Birnboim \& Doly, 1979) for the isolation of plasmid DNA.

Large-scale preparation of plasmid DNA. Cells from overnight cultures in NB (1 litre) containing $10 \mu \mathrm{g}$ tetracycline $\mathrm{ml}^{-1}$ were harvested at $4{ }^{\circ} \mathrm{C}$, washed in $500 \mathrm{ml}$ TEN buffer $(10 \mathrm{mM}$-Tris $/ \mathrm{HCl}$, $\mathrm{pH} 7.5 ; 10 \mathrm{~mm}$-EDTA, pH 8.0;150 mm-NaCl), and resuspended in $40 \mathrm{ml}$ lysozyme solution $(2 \%$, w/v, glucose; $10 \mathrm{~mm}$-Tris/ $\mathrm{HCl}, \mathrm{pH} 8.0$; $10 \mathrm{~mm}$-EDTA pH $8.0 ; 2 \mathrm{mg}$ lysozyme $\mathrm{ml}^{-1}$ ). The mixture was incubated at $37^{\circ} \mathrm{C}$ for $15 \mathrm{~min}$ then cells were lysed by the addition of $80 \mathrm{ml}$ of a $1 \%(\mathrm{w} / \mathrm{v})$ SDS solution containing $10 \mu \mathrm{g}$ heat-treated RNAase A ml-1 (Sigma). The pH of the lysate was adjusted to $12 \cdot 2-$ 12.8 with $0.2 \mathrm{M}-\mathrm{NaOH}$. After gentle mixing at $4{ }^{\circ} \mathrm{C}$ for $12 \mathrm{~min}, 60 \mathrm{ml}$ sodium acetate $(3 \mathrm{M}, \mathrm{pH} 4.8)$ was added and the mixture left at $4{ }^{\circ} \mathrm{C}$ for at least $1 \mathrm{~h}$. A cleared lysate was obtained by centrifugation at $27000 \mathrm{~g}$ for $30 \mathrm{~min}$ and filtering through cheesecloth. Plasmid DNA was concentrated by 2-propanol precipitation at room temperature for $30 \mathrm{~min}$. The precipitate was washed in $70 \%(\mathrm{v} / \mathrm{v})$ ethanol, dried and dissolved in $9 \mathrm{ml}$ TE buffer (10 mM-Tris/HCl, $\mathrm{pH} 8.0 ; 1$ mM-EDTA, $\mathrm{pH} \mathrm{8.0)}$. Caesium chloride $(9 \mathrm{~g})$ and ethidium bromide $(1 \mathrm{ml}$ of a $10 \mathrm{mg} \mathrm{ml}^{-1}$ stock solution) were added and $\mathrm{CsCl}-\mathrm{EtBr}$ equilibrium density gradient centrifugation was performed at 38000 r.p.m. for $65 \mathrm{~h}$ using an LKB ultracentrifuge (model 2330 Ultraspin 55, with RP55T rotor). Ethidium bromide was removed from plasmid bands by 2propanol extraction, and caesium chloride removed by dialysis against TES (20 mM-Tris/HCl, pH 8.0; 1 mM-EDTA, pH 8.0; $10 \mathrm{~mm}-\mathrm{NaCl})$. The dialysed sample $(500 \mu \mathrm{l})$ was then incubated at $-70^{\circ} \mathrm{C}$ for $30 \mathrm{~min}$ with $1 \mathrm{ml}$ ice-cold ethanol and $50 \mu \mathrm{l}$ sodium acetate $(3 \mathrm{M}, \mathrm{pH} 4.8)$. The precipitated plasmid DNA was dried, redissolved in TE and stored at $-20^{\circ} \mathrm{C}$ )

Restriction enzyme digestion and agarose gel electrophoresis. Plasmid DNA $(20 \mu \mathrm{l})$ was digested with restriction endonucleases HaelII and HindIII (Boehringer Mannheim) using conditions recommended by the manufacturer. The reaction was terminated by heating at $70^{\circ} \mathrm{C}$ for $10 \mathrm{~min}$. Electrophoresis was carried out in horizontal gels of $0.7 \%$ agarose in TBE buffer $(90 \mathrm{~mm}$-Tris/ $\mathrm{HCl} ; 90 \mathrm{~mm}$-boric acid; $2.5 \mathrm{mM}$ EDTA containing $0.2 \mu \mathrm{g}$ ethidium bromide $\mathrm{ml}^{-1}$ ). Plasmid sizes were estimated by comparison of band sizes with those of HindIII-digested phage $\lambda$ DNA

Electroelution of DNA bands from agarose gels. Plasmid DNA (200 $\mu 1)$ from Bacillus isolate MC58 (containing $640 \mu \mathrm{g} \mathrm{DNA} \mathrm{ml}^{-1}$ ) was loaded onto a horizontal agarose gel (as above). After electrophoresis, all DNA bands were excised and electroeluted (Maniatis et al., 1982). Eluted DNA fragments were digested with HaeIII.

Characterization of tetracycline-resistant isolates. Growth at 37, 50 and $65^{\circ} \mathrm{C}$ was tested by inoculating isolates onto NA agar with or without tetracycline $\left(25 \mathrm{\mu g} \mathrm{m}^{-1}\right)$ and examining plates after overnight incubation. Antibiotic sensitivity profiles were obtained by inoculating isolates onto NA containing one of the following antibiotics: chloramphenicol, ampicillin (both at $25 \mu \mathrm{g} \mathrm{ml}^{-1}$ ), streptomycin $\left(50 \mu \mathrm{g} \mathrm{ml}^{-1}\right)$, or kanamycin $\left(100 \mu \mathrm{g} \mathrm{ml}^{-1}\right)$. Plates were incubated for up to $48 \mathrm{~h}$ at $50^{\circ} \mathrm{C}$. For the determination of starch degradation, strains were inoculated onto NA containing $0.2 \%$ soluble starch $(\mathrm{BDH})$ and incubated for up to $72 \mathrm{~h}$ at $50^{\circ} \mathrm{C}$. Plates were then flooded with a solution of Gram's iodine and examined for zones of clearing indicative of starch hydrolysis.

Survival of B. subtilis containing pAB224 in compost samples. B. subtilis strain 168 was kindly provided by Richard Sharp (CAMR, Salisbury, UK). Plasmid pAB224 is a $3.0 \mathrm{~kb}$ deletion variant of a plasmid originally isolated from Bacillus stearothermophilus (Bingham et al., 1980); it carries a gene which confers tetracycline resistance upon the host (MIC $75 \mu \mathrm{g} \mathrm{ml}^{-1}$ ).

B. subtilis 168 containing pAB224 was cultured on NA plus $25 \mu \mathrm{g}$ tetracycline $\mathrm{ml}^{-1}$ for $48 \mathrm{~h}$ at $37^{\circ} \mathrm{C}$, and an inoculum was obtained by resuspending colonies in $10 \mathrm{ml}$ sterile distilled water. Compost samples ( $3 \mathrm{~g}$ of fresh or sterile compost in boiling tubes with loose-fitting caps) were inoculated with $0.5 \mathrm{ml}$ of the $B$. subtilis suspension to give an inoculum of $6 \times 10^{8} \mathrm{c}$.f.u. (g compost) $)^{-1}$. Where appropriate, compost was sterilized by autoclaving at $121{ }^{\circ} \mathrm{C}$ for $20 \mathrm{~min}$ on three successive days. Sterile distilled water $(0.5 \mathrm{ml})$ was added to uninoculated control tubes containing fresh compost. Tubes containing compost were incubated at either $37^{\circ} \mathrm{C}$ or $65^{\circ} \mathrm{C}$ for $28 \mathrm{~d}$; desiccation was prevented by monitoring weight and adjusting with sterile distilled water. Recoveries were made immediately after inoculation and at regular intervals following extraction and serial dilution in quarter-strength Ringer solution, as described previously (Amner et al., 1988). Dilutions $(0.1 \mathrm{ml})$ were plated onto NA with or without tetracycline $\left(25 \mu \mathrm{g} \mathrm{ml}^{-1}\right)$ and all plates were incubated at $37^{\circ} \mathrm{C}$ overnight. Spore counts were obtained by heating diluted compost samples at $90^{\circ} \mathrm{C}$ for $20 \mathrm{~min}$ prior to plating out. All experiments were performed in triplicate and data subjected to preliminary analysis by Student's $t$-test.

Maintenance of plasmid pAB224 was monitored throughout the incubation period by screening four to six randomly selected tetracycline-resistant $B$. subtilis isolates per compost sample, from triplicate compost samples. Isolates were inoculated into NB $(5 \mathrm{ml})$ containing $10 \mu \mathrm{g}$ tetracycline $\mathrm{ml}^{-1}$, shaken overnight at $37^{\circ} \mathrm{C}$, then subjected to the rapid alkaline extraction method (see above). In addition, a similar number of $B$. subtilis colonies recovered on nonselective plates from fresh compost, and all tetracycline-resistant isolates in the controls, were screened for plasmid DNA.

\section{Results}

\section{Isolation and classification of tetracycline-resistant} bacteria

An incubation temperature of $50^{\circ} \mathrm{C}$ was used in isolation experiments to select for thermotolerant and thermophilic groups of bacteria. We have previously analysed the bacterial populations of mushroom compost (Amner et al., 1988) and confirmed that virtually all bacteria isolated at $50{ }^{\circ} \mathrm{C}$ and exhibiting a non-hyphal growth form are members of the genus Bacillus (see Fermor $e t$ al., 1985). Low numbers of indigenous bacteria resistant to tetracycline were isolated from mushroom compost. This population represented a maximum of $10^{3}$ c.f.u. (g fresh compost) ${ }^{-1}$, compared to a total Bacillus population of $10^{8}$ c.f.u. $\mathrm{g}^{-1}$. Differences in colony morphology were used to select six representative tetracycline-sensitive 


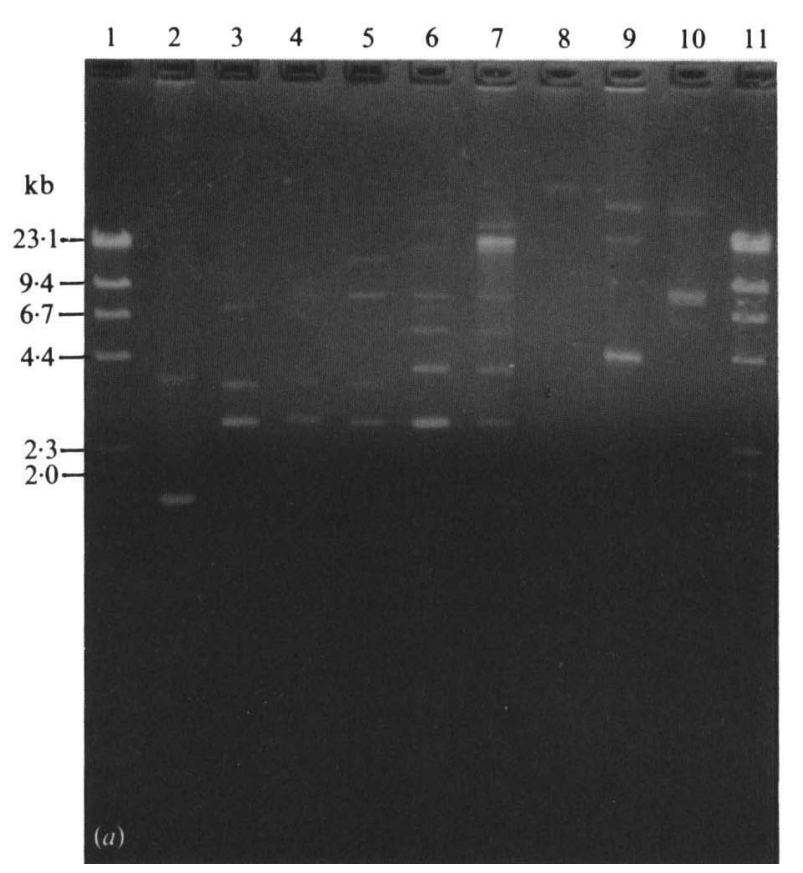

isolates, and these plus 52 tetracycline-resistant isolates were screened for the presence of plasmid DNA. Plasmids were detected in 17 tetracycline-resistant strains and their presence confirmed by large-scale plasmid preparation and purification on caesium chloride gradients. Plasmid DNA was not detected in any of the tetracycline-sensitive isolates tested.

Plasmid DNA preparations from all plasmid-bearing isolates, except strain CB10, gave multiple band patterns on agarose gels (Fig. 1a). This suggested the presence of more than one plasmid, but when the bands from one isolate (CB58) were electroeluted from agarose gels and restricted with $\mathrm{HaeIII}$, similar digest patterns emerged for the different bands (data not shown). In any event, the banding pattern of plasmid DNA from the indigenous tetracycline-resistant Bacillus strains was clearly distinct from that of pAB224 (Fig. $1 a$ ) and this could be readily confirmed by restriction with HaeIII (Fig. $1 b$ ).

Plasmid-bearing strains were classified into five groups according to apparent plasmid size and strain phenotype (Table 1). This simple classification scheme includes growth at $37^{\circ} \mathrm{C}$ and $65^{\circ} \mathrm{C}$ to differentiate thermotolerant and thermophilic species both of which grow at $50^{\circ} \mathrm{C}$, and starch hydrolysis, which is useful for the primary subdivision of thermophilic Bacillus strains (R. Sharp, CAMR, Salisbury, UK, personal communication). The majority of strains were unable to grow at $65^{\circ} \mathrm{C}$ and were sensitive to all of the antibiotics tested except tetracycline. The plasmid DNA extracted from these strains was approximately $10 \mathrm{~kb}$ in size, as determined by restriction analysis with endonucleases HaeIII (Fig. $1 b$ ) and HindIII. Two other isolates (CB9

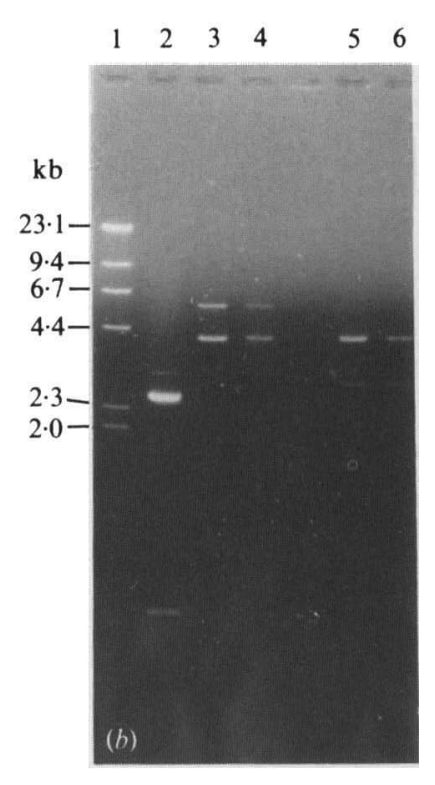

Fig. 1. Agarose gel electrophoresis of plasmids from tetracycline-resistant Bacillus isolates. (a) Uncut plasmid DNA : lanes 1 and 11, HindIII-digested phage $\lambda$ DNA size markers; lane 2 , pAB224; lanes 3 to 9, plasmid DNA from isolates $\mathrm{CB} 21, \mathrm{CB} 30, \mathrm{CB} 34$, CB58, $\mathrm{CB} 9, \mathrm{CB} 10$ and $\mathrm{CB} 18$; lane 10 , pTB90 (Imanaka et al., 1982). (b) Plasmid DNA restricted with HaeIII: lane $1, H$ indIII-digested phage $\lambda$ DNA size markers; lane 2, pAB224; lanes 3 to 6, plasmid DNA from isolates CB21, CB30, CB58 and CB9.

and CB58) appeared to carry smaller, $7 \mathrm{~kb}$ plasmids (Fig. 1 b). One of these isolates (CB9) was able to grow at $65^{\circ} \mathrm{C}$ and was resistant to $50 \mu \mathrm{g}$ streptomycin $\mathrm{ml}^{-1}$. The other isolate (CB58) was characterized by a mucoid colony form, sensitivity to streptomycin and resistance to ampicillin (Table 1). The other two tetracycline-resistant isolates (CB10 and CB18) showed similar characteristics to CB9 (Table 1) but appeared to carry larger plamids, $>25 \mathrm{~kb}$ in size, which had different restriction maps (data not shown). Isolates CB10 and CB18 differed from one another in their ability to degrade starch (Table 1).

\section{Survival of B. subtilis 168 containing pAB224 in sterile compost}

Data on the recovery of $B$. subtilis 168 as spores and total c.f.u. following release into sterile compost are presented in Fig. 2. In compost samples incubated at $37^{\circ} \mathrm{C}$, the population increased within the first $24 \mathrm{~h}$ after inoculation, then declined to a constant level of $10^{7}$ c.f.u. $\mathrm{g}^{-1}$ for the remaining 3 weeks of the incubation period (Fig. $2 a$ ). The proportion of the population recovered as spores increased from $0.0001 \%$ at inoculation to approximately $100 \%$ after $7 \mathrm{~d}$, indicating that $B$. subtilis 168 was persisting as spores throughout most of the incubation period. Some statistically significant differences $(P<0.01)$ were found between viable counts on tetracycline-amended and unamended media, appearing to indicate a possible loss of the plasmid-determined phenotype. However, because these differences were limited to days 1,3 and 28, this can be discounted. Furthermore, pAB224 DNA was readily recovered at 
Table 1. Characteristics of tetracycline-resistant Bacillus isolates which contained plasmid DNA

\begin{tabular}{|c|c|c|c|c|c|c|c|c|c|c|c|}
\hline \multirow[b]{2}{*}{$\begin{array}{c}\text { Strain } \\
\text { number }\end{array}$} & \multirow{2}{*}{$\begin{array}{l}\text { Apparent } \\
\text { plasmid } \\
\text { size } \\
(\mathrm{kb})\end{array}$} & \multicolumn{2}{|c|}{$\begin{array}{l}\text { Growth } \\
\text { at } 37^{\circ} \mathrm{C}^{*}\end{array}$} & \multicolumn{2}{|c|}{$\begin{array}{l}\text { Growth } \\
\text { at } 65^{\circ} \mathrm{C}^{*}\end{array}$} & \multirow[b]{2}{*}{$\begin{array}{c}\text { Starch } \\
\text { hydrolysis }\end{array}$} & \multirow{2}{*}{$\begin{array}{l}\text { Mucoid } \\
\text { colony } \\
\text { form }\end{array}$} & \multicolumn{4}{|c|}{$\begin{array}{l}\text { Additional drug resistances } \dagger \\
\text { detected }\left(\mu \mathrm{g} \mathrm{ml}^{-1}\right)\end{array}$} \\
\hline & & NA & $\begin{array}{c}\text { NA+ } \\
\text { Tet }\end{array}$ & NA & $\begin{array}{c}\mathrm{NA}+ \\
\text { Tet }\end{array}$ & & & $\begin{array}{r}\text { Kan } \\
(100)\end{array}$ & $\begin{array}{l}\text { Str } \\
(50)\end{array}$ & $\begin{array}{l}\text { Cam } \\
(25)\end{array}$ & $\underset{(25)}{\operatorname{Amp}}$ \\
\hline $\begin{array}{l}\text { CB21, 26, 28, } \\
29,30,31, \\
32,34,35, \\
37,38,41,42\end{array}$ & 10 & + & + & - & - & - & - & - & - & - & - \\
\hline CB9 & 7 & + & + & + & + & - & - & - & + & - & - \\
\hline CB58 & 7 & + & + & \pm & \pm & + & + & - & - & - & + \\
\hline CB 10 & $>25$ & + & + & + & + & + & - & - & + & - & - \\
\hline CB18 & $>25$ & + & + & + & - & - & - & - & + & - & - \\
\hline
\end{tabular}

* Growth was tested in the presence and absence of tetracycline (Tet) at $25 \mu \mathrm{g} \mathrm{ml}^{-1}$.

† Kan, kanamycin; Str, streptomycin; Cam, chloramphenicol; Amp, ampicillin.

every stage of the incubation period from all $B$. subtilis colonies that were screened (60-90 colonies in total).

In sterile compost samples incubated at $65^{\circ} \mathrm{C}$, the population of $B$. subtilis 168 (as recovered at $37^{\circ} \mathrm{C}$ ) declined steadily from $10^{8}$ to $10^{2}$ c.f.u. $\mathrm{g}^{-1}$ over $28 \mathrm{~d}$ (Fig. $2 b$ ). Throughout this time, the Bacillus counts recovered as spores were significantly lower $(P<0.01)$ than the total counts, particularly on the tetracycline-amended medium. However, there was no significant loss of tetracycline resistance within the total population and again plasmid DNA was readily extracted from all $B$. subtilis isolates screened (60-90 colonies).

\section{Survival of B. subtilis 168 containing pAB224 in fresh compost}

Survival of $B$. subtilis 168 in non-sterile compost was monitored by recovery of the strain from compost microcosms onto NA containing $25 \mu \mathrm{g}$ tetracycline $\mathrm{ml}^{-1}$ (Fig. 3). The pattern of survival was similar to that described above for sterile compost. In samples incubated at $37^{\circ} \mathrm{C}$, the population declined during the first week then stabilized at a lower level, presumably due to sporulation (Fig. $3 a$ ). In samples incubated at $65^{\circ} \mathrm{C}$, the population declined steadily throughout the incubation period and, with the exception of day 14, the total viable counts obtained were significantly greater $(P<0.01)$ than the equivalent spore counts (Fig. $3 b$ ). The decrease in population of $B$. subtilis at $65^{\circ} \mathrm{C}$ was not as marked in fresh compost as in sterile compost. Viable counts in excess of $10^{4}$ c.f.u. $\mathrm{g}^{-1}$ were recovered after $28 \mathrm{~d}$ in fresh compost, compared to $10^{2} \mathrm{~g}^{-1}$ from sterile compost (Fig. $2 b)$.

There appeared to be no loss of plasmid pAB224 from B. subtilis 168 in fresh compost at either incubation temperature. All of the randomly selected tetracyclineresistant $B$. subtilis isolates yielded plasmid DNA. In addition, plasmid DNA was recovered from $B$. subtilis isolates recovered on non-selective agar from fresh compost samples (120-180 colonies examined). We found that colonies of $B$. subtilis strain 168 were easily recognizable on isolation plates, and furthermore that careful examination of the other colonies enabled a preliminary classification based on colony morphology. The indigenous bacterial population consisted of two colony types: either small $(<3 \mathrm{~mm}$ in diameter) and fawn, or larger and lighter in colour. The colonies of $B$. subtilis 168 were of similar size to the larger of the two indigenous colony types, but were more translucent and easily distinguished when isolation plates were held to the light. No B. subtilis 168 colonies were recovered from uninoculated control compost samples, and this was the only colony type recovered on tetracycline-amended agar from inoculated samples. A small number of tetracycline-resistant colonies (less than three colonies per isolation plate at the detection limit of $10^{2} \mathrm{~g}^{-1}$ ) were isolated from uninoculated control samples incubated at $37^{\circ} \mathrm{C}$, on days 0,14 and 28 . These were found to contain plasmid DNA which did not co-migrate with pAB224 on agarose gels and which showed the typical multi-band pattern (see Fig. 1a). These plasmids were not characterized further.

Changes in the indigenous bacterial population in fresh compost were observed following recovery of bacteria on NA at $37^{\circ} \mathrm{C}$ (Fig. 3). The initial population of $10^{8}$ viable counts ( $\mathrm{g}$ compost) ${ }^{-1}$ decreased to a steady level of $10^{7} \mathrm{~g}^{-1}$ in compost incubated at $37^{\circ} \mathrm{C}$, compared to a decrease of more than two orders of magnitude in compost incubated at $65^{\circ} \mathrm{C}$. Spore counts generally equated with total counts in compost incubated at $37^{\circ} \mathrm{C}$, 

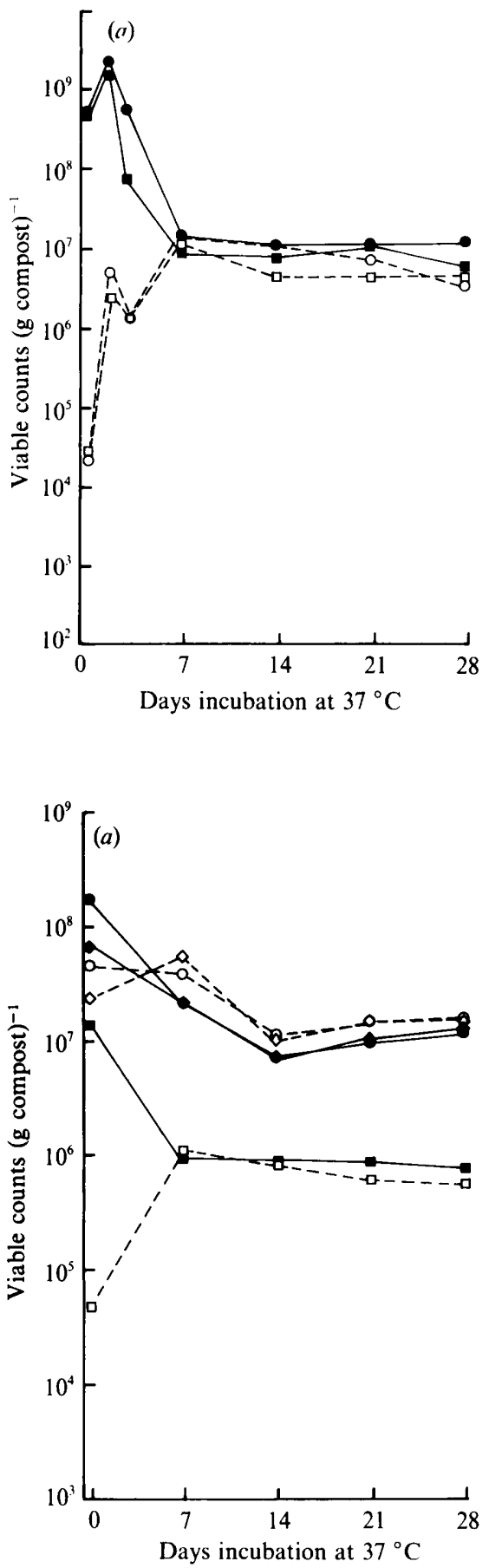
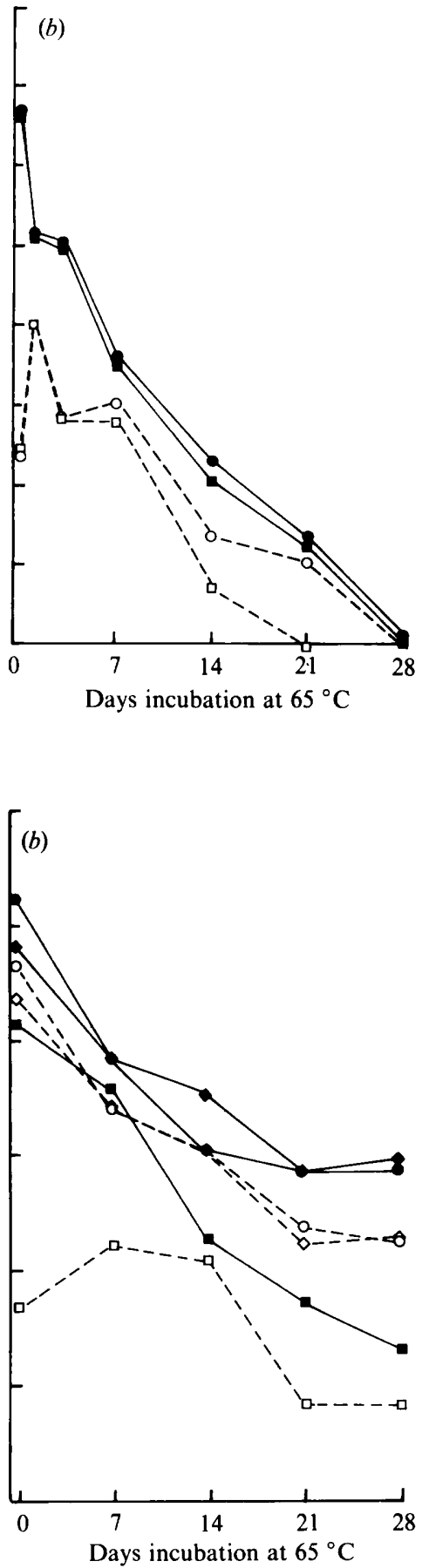

Fig. 2. Recovery of $B$. subtilis strain 168 containing pAB224 from sterile compost incubated at $(a)$ $37^{\circ} \mathrm{C}$ and $(b) 65^{\circ} \mathrm{C}$. Recovery at $37^{\circ} \mathrm{C}$ on NA: $\bullet$, total counts; $\mathrm{O}$, spore counts. Recovery at $37^{\circ} \mathrm{C}$ on NA containing tetracycline: $\mathbf{\square}$, total counts; $\square$, spore counts. All values are the means of triplicate determinations.
Fig. 3. Recovery of $B$. subtilis strain 168 containing pAB224 from, and population dynamics of indigenous bacteria in, fresh compost incubated at $(a) 37^{\circ} \mathrm{C}$ and $(b) 65^{\circ} \mathrm{C}$. Recovery of total population from uninoculated control composts at $37^{\circ} \mathrm{C}$ on NA: $\bullet$, total counts; $\diamond$, spore counts. Recovery of total population from $B$. subtilisinoculated composts at $37^{\circ} \mathrm{C}$ on NA: $\bullet$, total counts; $\mathrm{O}$, spore counts. Recovery of tetracyclineresistant population from composts inoculated with B. subtilis at $37^{\circ} \mathrm{C}$ on NA containing tetracycline: $\square$, total counts; $\square$, spore counts. All values are the means of triplicate determinations. but were lower in compost incubated at $65^{\circ} \mathrm{C}$. In both sets of fresh compost samples, inoculation with $B$. subtilis resulted in no significant increase $(P<0 \cdot 01)$ in total bacterial counts over control tubes, except on day 0 .

\section{Discussion}

Mushroom compost was selected as a model environment for studying survival of an introduced plasmidbearing $B$. subtilis strain because it is a relatively reproducible substrate with a highly active indigenous microflora in which Gram-positive bacteria, notably Bacillus spp. and actinomycetes, are abundant (Amner $e t$ al., 1988). Compost also provides a potential system for studying gene exchange between bacterial groups with different temperature optima since the indigenous population comprises both mesophilic and thermophilic species (Fermor et al., 1985). The ability of $B$. subtilis to grow at temperatures up to $50^{\circ} \mathrm{C}$ makes it useful for detecting gene transfer into both populations. This study 
was aimed at examining survival of $B$. subtilis host and vector in compost at both $37^{\circ} \mathrm{C}$ and $65^{\circ} \mathrm{C}$. Tetracycline resistance was chosen as the selectable marker for monitoring $B$. subtilis survival, since our previous studies had indicated an extremely low background resistance to tetracycline within the compost population (Amner $e t$ $a l .$, 1988). Characterization of this small tetracyclineresistant population, isolated from compost at $50^{\circ} \mathrm{C}$, revealed some plasmid-bearing strains. We distinguished four apparent plasmid types, one of 7, one of 10 and two of $>25 \mathrm{~kb}$ in size; these are within the size range of other plasmids detected in thermophilic Bacillus spp. (Bingham et al., 1979; De Rossi et al., 1989; Hoshino et al., 1985b; Imanaka et al., 1981). Preliminary restriction analysis including, for one isolate, that of electroeluted bands, suggested that the multiple bands of plasmid DNA (Fig. 1) were of a common origin within each strain. Examination of the electrophoretic separation of uncut plasmid DNA and the band intensities of restricted DNA do however reveal anomalies which limit the conclusions of these experiments. Multiple banding has previously been observed during the screening of thermophilic Bacillus strains for plasmids (De Rossi et al., 1989), and we have found this to be a very useful feature for distinguishing the introduced plasmid pAB224 from plasmid DNA in the indigenous microflora screened in this study. Southern hybridization experiments (results not shown) have provided evidence of homology between the plasmid DNA of tetracyclineresistant isolates and pAB224. Both cryptic and tetracycline-resistance plasmids have been shown to be closely related in Bacillus spp. (De Rossi et al., 1989; Hoshino et al., 1985a; Polack \& Novick, 1982), so it may not follow that the tetracycline resistance shown by such compost isolates is encoded by their plasmids. However, we have now transformed $B$. subtilis to tetracycline resistance with the $7 \mathrm{~kb}$ and $10 \mathrm{~kb}$ plasmid DNA listed in Table 1 (unpublished data). In view of these relationships, the application of colony hybridization methodology for the detection of pAB224 transfer events to this indigenous microflora would be limited unless stringency conditions could be satisfactorily increased or additional marker DNA inserted.

Inoculation of $B$. subtilis into a range of soil types has typically been accompanied by a drop in numbers, particularly in non-sterile soils (Acea et al., 1988; Van Elsas et al., 1987; 1988). Survival of B. subtilis strain 168 containing pAB224 in fresh compost incubated at $37^{\circ} \mathrm{C}$ was comparatively high, presumably due to sporulation and maintenance of populations in a dormant metabolic state. Survival at $65^{\circ} \mathrm{C}$ was reduced, but viable populations were maintained over a considerable period, especially in fresh compost. This degree of survival was surprising, since although thermophilic strains of $B$. subtilis have been produced by mutation in vitro (Droffner \& Yamamoto, 1985), the upper growth temperature of the $B$. subtilis strain used here was found to be $50{ }^{\circ} \mathrm{C}$. Sporulation within the $B$. subtilis population did not appear to be as complete in compost at $65^{\circ} \mathrm{C}$ as at $37^{\circ} \mathrm{C}$. However, these results could simply reflect the possibility that prolonged incubation of spores at $65^{\circ} \mathrm{C}$ followed by heating at $90^{\circ} \mathrm{C}$ for $20 \mathrm{~min}$ prior to plating out may cause a reduction in the viability of the spores sampled. The steady decline in numbers of $B$. subtilis at $65^{\circ} \mathrm{C}$ may be attributable to high-temperature induction of spore germination and subsequent lethal injury of vegetative forms at this temperature. Predation is unlikely to be a factor since protozoan populations have not been shown to have pronounced effects on Bacillus populations in soil (Casida, 1989), and predator numbers are expected to be low in compost due to the pasteurization phase of commercial mushroom preparation. Nutrient limitation is similarly expected to be unimportant since compost supports high populations of Bacillus spp. (Amner et al., 1988; Fermor et al., 1985) and because survival was found to be reduced in sterile compost where the autoclaving process would release bound nutrients, and competition with the indigenous population would be absent. The greater survival of $B$. subtilis in fresh rather than sterile compost at $65^{\circ} \mathrm{C}$ may be due to the release of excess or toxic nutrients by the combined effects of compost sterilization and high-temperature incubation, or the provision of growth-promoting substances by the indigenous microflora.

There was no apparent loss of plasmid pAB224 in compost. This study therefore demonstrates how an introduced plasmid can survive in a natural population even in the absence of selective pressure. This, together with the maintenance of viable Bacillus populations at both $37^{\circ} \mathrm{C}$ and $65^{\circ} \mathrm{C}$, provides an opportunity for studying gene exchange between mesophilic and thermophilic populations. Gene exchange between Bacillus strains has previously been demonstrated in soil (Graham \& Istock, 1978; Van Elsas et al., 1987), and gene exchange between mesophilic and thermophilic groups has been demonstrated in vitro (Imanaka \& Aiba, 1986). Gene transfer may be limited due to the production of metabolically inactive spores by the introduced and the indigenous populations. Future experiments will be aimed at increasing the possibilities for gene transfer by, for example, nutrient amendements to compost to maintain vegetative cell rather than spore populations. Furthermore, recombinant plasmids containing appropriate combinations of selectable markers are being developed from the work described here, in order to enable more rigorous evaluation of plasmid survival and transfer potential. The increased longevity of endosporeforming bacteria has important implications for the 
long-term survival of genetically-engineered microorganisms in the environment.

This work was supported by a grant from the Natural Environment Research Council.

We gratefully acknowledge D. T. K. Beardsell (Beardsell Mushroom Growers Ltd) for the provision of compost samples, and thank Paul Fieldsend for technical assistance. We are also grateful to Richard Sharp and Paul Riley of CAMR, Salisbury, UK, for helpful discussions, and Dr S. Baumberg, University of Leeds, for advice on presentation.

\section{References}

Acea, M. J., Moore, C. R. \& Alexander, M. (1988). Survival and growth of bacteria introduced into soil. Soil Biology and Biochemistry 20, 509-515.

Aiba, S., KitaI, K. \& ImanaKa, T. (1983). Cloning and expression of thermostable $\alpha$-amylase gene from Bacillus stearothermophilus in Bacillus stearothermophilus and Bacillus subtilis. Applied and Environmental Microbiology 46, 1059-1065.

AMNER, W., MCCARTHY, A. J. \& EDWARDS, C. (1988). Quantitative assessment of factors affecting the recovery of indigenous and released thermophilic bacteria from compost. Applied and Environmental Microbiology 54, 3107-3112.

BentJen, S. A., Fredrickson, J. K., Van Voris, P. \& Li, S. W. (1989). Intact soil-core microcosms for evaluating the fate and ecological impact of the release of genetically engineered microorganisms. Applied and Environmental Microbiology 55, 198-202.

Bingham, A. H. A., Bruton, C. J. \& Atxinson, T. (1979). Isolation and partial characterization of four plasmids from antibioticresistant thermophilic bacilli. Journal of General Microbiology 114, 401-408.

Bingham, A. H. A., Bruton, C. J. \& Atkinson, T. (1980). Characterization of Bacillus stearothermophilus plasmid PAB124 and construction of deletion variants. Journal of General Microbiology 119, 109-115.

Birnbolm, H. C. \& Doly, J. (1979). A rapid alkaline extraction procedure for screening recombinant plasmid DNA. Nucleic Acids Research 7, 1513-1523.

Bleakley, B. H. \& CRAWford, D. L. (1989). The effects of varying moisture and nutrient levels on the transfer of a conjugative plasmid between Streptomyces species in soil. Canadian Journal of Microbiology 35, 544-549.

CASIDA, L. E. (1989). Protozoan response to the addition of bacterial predators and other bacteria in soil. Applied and Environmental Microbiology 55, 1857-1859.

De Rossi, E., Brigidi, P., Riccardi, G. \& Matteuzzi, D. (1989). Plasmid screening in thermophilic Bacillus: physical characterization and molecular cloning. Current Microbiology 19, 13-19.

Devanas, M. A. \& Stotzky, G. (1986). Fate in soil of a recombinant plasmid carrying a Drosophila gene. Current Microbiology 13, 279283.

DRofFNeR, M. L. \& YAMAMoto, N. (1985). Isolation of thermophilic mutants of Bacillus subtilis and Bacillus pumilus and transformation of the thermophilic trait to mesophilic strains. Journal of General Microbiology 131, 2789-2794.

Fermor, T. R., RANDLE, P. E. \& SMith, J. F. (1985). Compost as a substrate and its preparation. In The Biology and Technology of the Cultivated Mushroom, pp. 81-109. Edited by P. B. Flegg, D. M. Spencer \& D. A. Wood. Chichester: John Wiley.

Genthner, F. J., Chatterjee, P., Barkay, T. \& Bourquin, A. W. (1988). Capacity of aquatic bacteria to act as recipients of plasmid DNA. Applied and Environmental Microbiology 54, 115-117.

GraHAM, J. B. \& IsTock, C. A. (1978). Genetic exchange in Bacillus subtilis in soil. Molecular and General Genetics 166, 287-290.

Hoshino, T., Ikeda, T., Furukawa, K. \& Tomizuka, N. (1985a). Genetic relationship between pUB110 and antibiotic resistant plasmids obtained from thermophilic bacilli. Canadian Journal of Microbiology 31, 614-619.
Hoshino, T., Ikeda, T., Narushima, H. \& Tomizuka, N. (1985b). Isolation and characterization of antibiotic-resistance plasmids in thermophilic bacilli. Canadian Journal of Microbiology 31, 339-345.

ImANAKA, T. \& AIBA, S. (1986). Applied genetics of aerobic thermophiles. In Thermophiles. General Molecular and Applied Microbiology, pp. 159-178. Edited by T. D. Brock, New York: John Wiley.

Imanaka, T., FujII, M. \& AIBA, S. (1981). Isolation and characterization of antibiotic resistance plasmids from thermophilic bacilli and construction of deletion plasmids. Journal of Bacteriology 146, 10911097.

ImaNAKa, T., FUJI, M., ARAmori, I. \& Aiba, S. (1982). Transformation of Bacillus stearothermophilus with plasmid DNA and characterization of shuttle vector plasmids between Bacillus stearothermophilus and Bacillus subtilis. Journal of Bacteriology 149, 824-830.

KRASOvSKy, V. N. \& STOTzKY, G. (1987). Conjugation and genetic recombination in Escherichia coli in sterile and nonsterile soil. Soil Biology and Biochemistry 19, 631-638.

Maniatis, T., Fritsch, E. F. \& SAmbrook, J. (1982). Molecular Cloning: a Laboratory Manual. Cold Spring Harbor, NY: Cold Spring Harbor Laboratory.

MiYagawa, K., Kanzaki, N., Kimura, H., Sumino, Y., AkiYama, S. \& NAKAO, Y. (1989). Increased inosine production by a Bacillus subtilis xanthine-requiring mutant derived by insertional inactivation of the IMP dehydrogenase gene. Biotechnology 7, 821-824.

Morel, J. L., Bitton, G., Chaudhry, G. R. \& Awong, J. (1989). Fate of genetically modified microorganisms in the corn rhizosphere. Current Microbiology 18, 355-360.

NaKamuRa, K. \& ImanaKa, T. (1989). Expression of the insecticidal protein gene from Bacillus thuringiensis subsp. aizawai in Bacillus subtilis and in the thermophile Bacillus stearothermophilus by using the $\alpha$-amylase promoter of the thermophile. Applied and Environmental Microbiology 55, 3208-3213.

PAYNe, C. C. (1988). Pathogens for the control of insects: where next? Philosophical Transactions of the Royal Society London B318, 225-248.

Polack, J. \& Novick, R. P. (1982). Closely related plasmids from Staphylococcus aureus and soil bacilli. Plasmid 7, 152-162.

PrIest, F. G. (1977). Extracellular enzyme synthesis in the genus Bacillus. Bacteriological Reviews 41, 711-753.

RAFII, F. \& CRAWFORD, D. L. (1988). Transfer of conjugative plasmids and mobilization of a nonconjugative plasmid between Streptomyces strains on agar and in soil. Applied and Environmental Microbiology 54, 1334-1340.

Richaume, A., Angle, J. S. \& Sadowsky, M. J. (1989). Influence of soil variables on in situ plasmid transfer from Escherichia coli to Rhizobium fredii. Applied and Environmental Microbiology 55, 17301734.

STOTZKY, G. \& BABICH, H. (1986). Survival of, and genetic transfer by, genetically engineered bacteria in natural environments. Advances in Applied Microbiology 31, 93-138.

Trevors, J. T. \& Berg, G. (1989). Conjugal RP4 transfer between pseudomonads in soil and recovery of RP4 plasmid DNA from soil. Systematic and Applied Microbiology 11, 223-227.

Trevors, J. T., Barkay, T. \& Bourguin, A. W. (1987). Gene transfer among bacteria in soil and aquatic environments: a review. Canadian Journal of Microbiology 33, 191-198.

Van Elsas, J. D., GovaerT, J. M. \& Van Veen, J. A. (1987). Transfer of plasmid pFT30 between bacilli in soil as influenced by bacterial population dynamics and soil conditions. Soil Biology and Biochemistry 19, 639-647.

Van Elsas, J. D., Trevors, J. T. \& Starodub, M. E. (1988). Plasmid transfer in soil and rhizosphere. In Risk Assessment for Deliberate Release, pp. 89-99. Edited by W. Klingmuller. Berlin: SpringerVerlag.

Wang, Z., Crawford, D. L., Pometto, A. L. \& Rafil, F. (1989). Survival and effects of wild-type, mutant and recombinant Streptomyces in a soil ecosystem. Canadian Journal of Microbiology 35, 535543.

Wellington, E. M. H., Saunders, V. A., Cresswell, N. \& Wipat, A. (1988). Plasmid transfer between streptomycetes in soil. In Biology of Actinomycetes ' 88 , pp. 300-305. Edited by Y. Okami, T. Beppu \& H. Ogawara. Tokyo: Japan Scientific Societies Press. 